\title{
ESSAY
}

\section{PRINCIPLES, PRACTICES, AND SOCIAL MOVEMENTS}

\author{
JACK M. BALKIN ${ }^{\dagger} \&$ REVA B. SIEGEL ${ }^{\dagger+}$

\section{PRINCIPLES AND PRACTICES}

Consider two current controversies in American law and politics: the first is whether the expansion of copyright, trademark, and other forms of intellectual property conflicts with the free speech principle; the second is whether government collection and use of racial data (in the census or in law enforcement) violates the antidiscrimination principle. What do these controversies have in common? Both involve constitutional challenges that call into question the legitimacy of existing practices. More importantly, these examples teach us something about how constitutional principles operate. In each case, controversy arises as people apply a longstanding principle to a longstanding practice-a practice that heretofore has not been understood to be implicated by the principle. People exercise creativity by applying the principles to these previously uncontroversial practices, and as they do, they can reshape the meaning of both the principle and the practice.

The claim that a longstanding practice violates a longstanding principle draws into question not only the legitimacy of the practice, but also the authority and the scope of the principle. While some argue that the free speech principle delegitimates expansion of copyright terms and other intellectual property rights, others insist that the challenged practice is fully consistent with the free speech principle: restrictions on infringement of intellectual property rights regulate conduct, not speech, and the fair use defense and the idea/ expression distinction adequately protect free speech interests in

\footnotetext{
${ }^{\dagger}$ Knight Professor of Constitutional Law and the First Amendment, Yale Law School.

${ }^{\dagger+}$ Nicholas deB. Katzenbach Professor, Yale Law School.
} 
copyright law. ${ }^{1}$ While some think that the use of racial data (in the census or in law enforcement) violates the antidiscrimination principle, ${ }^{2}$ others contend that the principle does not apply to data collection $^{3}$ or does not apply when the government collects racial data from private parties (witnesses to crimes or people who voluntarily report their race to the census). ${ }^{4}$

Does the free speech principle call into question copyright or does copyright raise disturbing questions about the scope and meaning of the free speech principle? Does the antidiscrimination principle call into question the census and suspect descriptions or do the census and suspect descriptions raise disturbing questions about the scope and meaning of the antidiscrimination principle? As these examples illustrate, when advocates apply constitutional principles in new ways, they can create conflicts between longstanding principles and longstanding practices so that one customary understanding calls into question the other.

This Essay is about the ways that principles and practices can draw each other's authority into question, and about the role that political contestation plays in spurring those challenges. We offer three basic points. First, legal principles are intelligible and normatively authoritative only insofar as they presuppose a set of background understandings about the paradigmatic cases, practices, and areas of social life to which they properly apply. A principle always comes with an imagined regulatory scene that makes the meaning of the principle coherent to us. When that background understanding is disturbed the principle becomes "unstuck" from its hermeneutic moorings; it no longer seems clear how the principle applies or even whether it should apply.

Second, political contestation plays an important role in shaping understandings about the meaning and application of constitutional principles. Although we often invoke constitutional principles as commitments that transcend everyday political contestation, political contestation can change popular and professional intuitions about the proper application of constitutional principles. Social movements challenge background understandings about the paradigmatic cases,

\footnotetext{
${ }^{1}$ See, e.g., Eldred v. Ashcroft, 537 U.S. 186, 219-20 (2003) (rejecting calls for First Amendment scrutiny of the Sonny Bono Copyright Term Extension Act, Pub. L. No. 105-298, 112 Stat. 2827 (1988), because "copyright law contains built-in First Amendment accommodations").

${ }^{2}$ See infra note 37 and accompanying text.

3 See infra note 39 and accompanying text.

${ }^{4}$ See infra notes 40, 44 and accompanying text.
} 
practices, and areas of social life to which principles properly apply; with sustained contestation, constitutional principles become "unstuck." As social movements challenge the conventions that regulate the application of principles, longstanding principles can call into question the legitimacy of customary practices (e.g., racial profiling, racial segregation, or sexual harassment) or imbue with constitutional value practices long judged illicit (e.g., abortion, pornography, samesex sodomy, or same-sex marriage). When movements succeed in contesting the application of constitutional principles, they can help change the social meaning of constitutional principles and the practices they regulate.

Third, movements acting alone are rarely able to destabilize the meaning of constitutional principles; more often, movements take advantage of broad-based social, economic, or technological changes that unsettle conventional understandings about the jurisdiction of constitutional principles in order to make new claims about the proper application of constitutional principles. There is typically more than one way to do this. Groups with competing interests may avail themselves of the opportunity presented by social, economic, and technological change to try to push the law in their favored direction.

In sum, political contestation can alter what people think constitutional principles mean and how principles should apply in practice. ${ }^{5}$ Principles once uncontroversially accepted become counterintuitive and produce uncomfortable results as they are applied to new situations and problems; fields of law that rely on these principles become

\footnotetext{
${ }^{5}$ For a demonstration of how the antidiscrimination principle was forged in decades of social movement conflict over Brown v. Board of Education, 347 U.S. 483 (1954), see Reva B. Siegel, Equality Talk: Antisubordination and Anticlassification Values in Constitutional Struggles Over Brown, 117 HARV. L. REv. 1470, 1474-75 (2004) [hereinafter Siegel, Equality Talk] ("The understanding that anticlassification and antisubordination are competing principles that vindicate different complexes of values and justify different doctrinal regimes is an outgrowth of decades of struggle over Brown, and is not itself a ground of the decision or of the earliest debates it prompted."). Social movement advocacy played an equally central role in forging the meaning of the antidiscrimination principle in matters concerning sex and the family. See Reva B. Siegel, Constitutional Culture, Social Movement Conflict and Constitutional Change: The Case of the De Facto ERA, 94 CAL. L. REV. (forthcoming Oct. 2006) [hereinafter Siegel, Constitutional Culture] (describing how mobilization for and against the Equal Rights Amendment gave life and limits to sex discrimination doctrine under the Fourteenth Amendment).
} 
contentious. ${ }^{6}$ This is what happened to the antidiscrimination principle in the 1970s when affirmative action became a major bone of contention. ${ }^{7}$ It also happened to the First Amendment, when issues like telecommunications regulation and campaign finance became central concerns of free speech theory. ${ }^{8}$

\section{How Constitutional PRinciples Become UnSTUCK}

Principles are norms of conduct that express values. They exist at higher and lower levels of generality, so that some principles justify other principles. Here are four examples of principles that concern race and freedom of speech:

(1) government should not discriminate on the basis of forbidden categories (e.g., race, sex, etc.) (the antidiscrimination principle);

(2) government should not make classifications on the basis of forbidden categories (the anticlassification principle);

(3) government should not violate the free speech rights of people (the free speech principle);

(4) government should not treat speech differently because of its content (the no-content-discrimination principle).

Note that principles (2) and (4) are often justified on the grounds that they enact principles (1) and (3). In other words, people justify the anticlassification principle on the grounds that government should not discriminate (the antidiscrimination principle), and people justify the ban on content discrimination on the grounds that government should protect individuals' freedom of speech.

Principles like the four mentioned above do not determine the scope of their own application. We understand them as norms of conduct of general applicability that apply to a wide variety of social

\footnotetext{
${ }^{6}$ This is a special case of a phenomenon one of us has called "ideological drift." See J.M. Balkin, Ideological Drift and the Struggle over Meaning, 25 CONN. L. REV. 869, 870 (1993); J.M. Balkin, Some Realism About Pluralism: Legal Realist Approaches to the First Amendment, 1990 Duke L.J. 375, 383 [hereinafter Balkin, Some Realism About Pluralism].

${ }^{7}$ See Jack M. Balkin \& Reva B. Siegel, The American Civil Rights Tradition: Anticlassification or Antisubordination?, 58 U. MIAMI L. REV. 9, 28-32 (2003) [hereinafter Balkin \& Siegel, The American Civil Rights Tradition] (describing the end of the "Second Reconstruction" and the role of the anticlassification and antisubordination doctrines during the 1960s and 1970s); Siegel, Equality Talk, supra note 5, at 1513-32 (describing the historical development of the Court's "colorblindness" approach in the 1960s and 1970s).

${ }^{8}$ See Balkin, Some Realism About Pluralism, supra note 6, at 378-86 (discussing legal realist critiques of the First Amendment in light of free speech concerns about campaign finance laws).
} 
practices. Yet, even though principles like the anticlassification principle and the no-content-discrimination principle seem to apply generally, they retain an implicit connection with the regulatory scene in which their value commitments were first forged. Principles first become intelligible and authoritative in concrete contexts; over time they continue to get normative heft from being embedded in discrete contexts of judgment.

Any articulation of a constitutional principle presupposes a paradigmatic set of problems that the principle is supposed to resolve and a particular set of paradigmatic practices that the principle legitimates or delegitimates. We might call this set of problems and practices the "regulatory scene." For example, the regulatory scene for the anticlassification principle is the practice of Jim Crow, and in particular, the racial segregation of school children challenged in Brown v. Board of Education. ${ }^{9}$ The regulatory scene for the no-content-discrimination principle is the practice of state censorship or repression of dissent, and in particular, the imposition of fines or criminal penalties on people who express unpopular viewpoints or criticize government policy. That is to say, the anticlassification principle makes particular normative sense when it is applied to de jure school segregation to explain why that practice is illegitimate. Similarly, the no-contentdiscrimination principle makes particular normative sense when it is applied to government prosecution of anti-war protesters or Communist sympathizers to explain why that practice is illegitimate. The principle is given coherence by its regulatory scene; conversely, practices that appear to correspond to that regulatory scene are legitimated or delegitimated by reference to the principle. The paradigmatic cases and practices in which we imagine the principle to have normative force offer us a sense of security about how that principle should operate in practice. We understand the meaning of constitutional principles with explicit or implicit reference to practice.

But this state of affairs-where a principle reinforces the meaning of the practices conventionally associated with it-is disturbed from time to time. When a principle is applied in unconventional ways, uncertainty of two sorts results. First, application of the principle to unconventional practices may produce controversy about the jurisdiction

${ }^{9}$ Jim Crow refers to the system of racial apartheid in the United States in the century after the abolition of slavery, which expressed and enforced white supremacy in the discourse of "separate but equal." Brown overruled this doctrine in the field of public education. See 347 U.S. at 495 ("Separate educational facilities are inherently unequal."). 
of the principle. When we move from Jim Crow to race-based suspect descriptions (e.g., "the perp was African American, young, with a scar on his right hand"), we do not know whether the anticlassification principle applies: we do not know whether race-based suspect descriptions are classifications that fall within the principle. When we move from prosecutions of anti-war protesters to the constitutionality of must-carry rules ${ }^{10}$ or injunctions for copyright infringement, we do not know whether these practices are discriminations on the basis of content to which strict scrutiny might apply.

Second, application of the principle to unconventional practices may produce controversy about the justification of the principle. Some may approve of the new application of the principle, while others may view the new application as in tension with the values that they supposed compliance with the principle would promote. In this way, disputes arise about which values the principle is supposed to vindicate. The problem of affirmative action, for example, makes controversial whether the anticlassification principle really does serve the antidiscrimination principle in all cases. The problem of regulating speech by government employees or regulating speech through conditional subsidies puts into question whether the no-content-discrimination principle correctly vindicates the free speech principle. The application of the principle to new practices produces debate about the underlying values promoted by the law governing these fields. Such dispute is simultaneously positive and normative. Participants will debate the values that law has long promoted and the values that law ought to promote.

How do such disputes about the jurisdiction of principles arise? Sometimes questions about the jurisdiction of a principle arise out of a change in people's interpretation of the social world, rather than some change in technology, economics, or social structure. At other times, technological, economic, or social change makes the scope of a principle's application uncertain. Yet in these cases, it is rarely technological or economic innovation alone that causes a principle to come unstuck; even these changes are filtered through interpretation. More than one interpretation is possible; groups with different interests will view the change as a threat to settled practices or as a golden

${ }^{10}$ See Turner Broad. Sys., Inc. v. FCC, 512 U.S. 622, 626, 667-68 (1994) (upholding the constitutionality of the so-called "must-carry" provision of the Cable Television Consumer Protection and Competition Act of 1992, Pub. L. No. 102-385, 106 Stat. 1460 , which requires cable television system operators to set aside some of their channels for local television broadcasts). 
opportunity to reform customary practice, and so urge different legal responses to change.

For this reason, technological and economic changes produce political contestation and social movement organization that in turn mediate the significance of such changes in the legal system. Copyright is a good example. In the most abstract sense, copyright and freedom of speech have always been in potential conflict. But the conflict only became particularly important at a certain point in history, as technological change and mobilization by stakeholders made salient features of the world that were previously in the background. ${ }^{11}$ Groups responded to the rise of digital technologies by mobilizing to secure particular modes of regulation. Intellectual property stakeholders mobilized to secure their rights in the face of new methods of content creation and distribution, and to expand their markets even further. ${ }^{12}$ This prompted countermobilization by various software developers, early adopters of the new technologies, and consumer advocates who argued that intellectual property must be limited by the technological changes wrought by the digital age. ${ }^{13}$ Both groups responded to the disruption caused by technological change-but they responded in different ways. Conflicting interpretations of what is happening, and conflicting interests in light of those interpretations, produce the contest over the understanding of the regulatory scene.

\section{TWO EXAMPLES}

We opened this Essay with two examples of areas where people are presently contesting the jurisdiction of longstanding constitutional principles. In each of these areas, the legal system is beginning to consider whether a legal principle applies to a practice that for long stretches of time simply did not appear to be within its jurisdiction. Our first example concerned how the free speech principle applies to copyright. The second example concerned the question of whether the antidiscrimination principle applies to government collection of data about an individual's race. We now look at each of these cases more closely, with the aim of considering the kinds of changes that

${ }^{11}$ See Jack M. Balkin, Digital Speech and Democratic Culture: A Theory of Freedom of Expression for the Information Society, 79 N.Y.U. L. REV. 1, 13-19 (2004) (describing the "social contradiction" of the digital age, which leads to struggles over control of information production and, in particular, new conflicts between freedom of speech and intellectual property).

${ }^{12}$ See infra text accompanying notes 28-31.

${ }^{13}$ See infra text accompanying note 27. 
prompt shifts in intuitions about the proper application of constitutional principles.

Our inquiry suggests that significant changes in technology, economics, demographics, or law may motivate political actors to struggle anew over the meaning of constitutional principles. Changes in the ecology of a principle's application create uncertainty about the principle's meaning, which in turn provides incentive and opportunity for interested parties to propose new accounts of the principle's jurisdiction. As political actors make new claims about the application of principles to practices, they draw other citizens and officials into a dynamic that can infuse constitutional law with new normative energy and change the ways it regulates the institutions of civil society.

\section{A. Copyright}

The free speech principle only began to generate a significant amount of attention from the Supreme Court following World War I. ${ }^{14}$ It would take almost forty years for the Court to articulate the free speech principle through a significant body of doctrine and arrive at the conclusion that restrictions on the basis of content are suspect and deserve strict scrutiny. The civil rights movement changed understandings about the reach and scope of the free speech principle. Older practices of regulating pornography, indecency, defamation, and fighting words-practices whose constitutionality was taken for granted-became problematized and delegitimated in cases like New York Times Co. $v$. Sullivan. ${ }^{15}$ As the reach of the free speech principle expanded, it threatened to delegitimate forms of regulation, including broadcast regulation, that until then had been treated as constitutionally unproblematic. As these concerns came into view, the Supreme Court devised a theory to justify traditional forms of broadcast regulation in Red Lion Broadcasting Co. v. FCC. ${ }^{16}$ Similarly, the Court

\footnotetext{
${ }^{14}$ See, e.g., Gitlow v. New York, 268 U.S. 652, 666, 671 (1925) (holding that government may criminally proscribe the advocacy of anarchy, even if First Amendment guarantees of free speech and assembly are incorporated against the states).

${ }^{15} 376$ U.S. 254 (1964) (holding that the First Amendment bars suits for defamation by public officials when publication is not made with knowing or reckless disregard for falsity).

${ }^{16} 395$ U.S. 367 (1969) (justifying broadcast regulation on the grounds of spectrum scarcity).
} 
came up with ways of justifying (some) regulations of campaign finance in Buckley $v$. Valeo. ${ }^{17}$

The first wave of theorizing about free speech and copyright occurred in this period. If pornography, indecency, and defamation were protected by the free speech principle, why not copyright infringement? In the early 1970s, Paul Goldstein and Melville Nimmer wrote two key articles explaining the proper interaction between copyright and the First Amendment. ${ }^{18}$ Goldstein, influenced both by Red Lion and Jerome Barron's work on access to the mass media, ${ }^{19}$ viewed copyright as a method of balancing the competing speech interests of speakers and the mass media. ${ }^{20}$ Nimmer, influenced by the Court's special rules for libel, obscenity, and fighting words, solved the problem through the notion of "definitional balancing." ${ }^{21}$ Instead of balancing the costs and benefits of speech regulation case by case, Nimmer argued, the First Amendment carved out particular classes of speech-like obscenity, defamation, and fighting words-as subject to limited forms of legislative regulation, even if the definition of these areas was based on the content of expression. ${ }^{22}$ Copyrighted expression was yet another category of speech regulable by Congress, subject to key First Amendment protections in doctrines like fair use, ${ }^{23}$ the idea/expression distinction, ${ }^{24}$ the first sale doctrine, ${ }^{25}$ and the requirement of limited terms for copyrights. ${ }^{26}$ Nimmer's solution, like Goldstein's, stabilized the conflict between free speech and copyright for a time.

${ }^{17} 424$ U.S. 1 (1976) (upholding limitations on individual campaign contributions on the grounds of preventing corruption, while striking down limits on individual expenditures for advocacy on behalf of candidates).

${ }^{18}$ Paul Goldstein, Copyright and the First Amendment, 70 CoLuM. L. REV. 983 (1970); Melville B. Nimmer, Does Copyright Abridge the First Amendment Guarantees of Free Speech and Press?, 17 UCLA L. REV. 1180 (1970).

19 See Jerome A. Barron, Access to the Press: A New First Amendment Right, 80 HARV. L. REV. 1641, 1650-56 (1967) (arguing that mass media have affirmative responsibilities to grant access to speakers).

${ }^{20}$ See Goldstein, supra note 18, at 988 (describing two "accomodative principles" for reconciling the competing interests in copyright infringement cases).

${ }^{21}$ See Nimmer, supra note 18, at 1184 (explaining the Court's use of "definitional balancing" to "determin[e] which forms of speech are to be regarded as 'speech' within the First Amendment").

${ }^{22}$ See id. (arguing that these classes of speech fall outside the First Amendment's ambit).

${ }^{23} 17$ U.S.C. $\$ 107$ (2000).

${ }^{24} I d$. $102(\mathrm{~b})$.

${ }^{25}$ Id. $\$ 109$.

${ }^{26}$ U.S. CONST. art. 1, § 8, cl. 8. 
That resolution was disturbed in the early 1990s with the growth and commercialization of the Internet. But the disturbance was not simply due to technological change. It was because particular stakeholders understood the change as threatening their existing interests in intellectual property and sought to respond to it, while other groups saw the conflict between speech and copyright as a welcome opportunity to end or at least greatly cut back on traditional copyright protections. ${ }^{27}$ Perhaps not surprisingly, media corporations with concentrated interests in intellectual property had the best lobbying power and gained the ear of government officials, while the countermobilization remained largely impotent for many years. The 1995 white paper on Intellectual Property and the National Information Infrastructure called for significant reforms in copyright law in order to protect the interests of intellectual property owners, ${ }^{28}$ leading ultimately to the passage of the Digital Millennium Copyright Act (DMCA) ${ }^{29}$ and the Sonny Bono Copyright Term Extension Act. ${ }^{30}$ Media companies began to assert intellectual property rights more aggressively, even in areas that had little to do with the new digital technologies, as exemplified by the controversy over Alice Randall's The Wind Done Gone. ${ }^{31}$

At the same time, new social movements formed that promoted the idea of freely available information and viewed strong protections

${ }^{27}$ See, e.g., John Perry Barlow, The Economy of Ideas, WiRED, Mar. 1994, at 85, 129, available at http://www.wired.com/wired/archive/2.03/economy.ideas.html (arguing that "almost everything we think we know about intellectual property is wrong" and that the digital age will produce new business models not primarily based on exploitation of traditional intellectual property rights).

${ }^{28}$ INTELlECTUAL PROPERTY AND THE NATIONAL INFORMATION INFRASTRUCTURE: The RePORT OF THE WORkING GROUP ON INTEllectual Property 213-21 (1995), available at http://www.uspto.gov/web/offices/com/doc/ipnii/ipnii.pdf (recommending amendments to the Copyright Act to deal with transmission issues raised by changing technology).

${ }^{29}$ Pub. L. No. 105-304, 112 Stat. 2860 (1998) (codified at 17 U.S.C. $\$ 1201$ (2000)) (prohibiting the circumvention of technology used to control access to copyrighted works).

${ }^{30}$ Pub. L. No. 105-298, 112 Stat. 2827 (1998) (codified in scattered sections of 17 U.S.C.) (extending copyrights by amending previous law). See generally Pamela Samuelson, The Copyright Grab, WIRED, Jan. 1996, at 135, available at http://www.wired.com/ wired/archive/4.01/white.paper_pr.html (examining the white paper's impact on subsequent legislation).

${ }^{31}$ See Suntrust Bank v. Houghton Mifflin Co., 268 F.3d 1257, 1276 (11th Cir. 2001) (holding that Alice Randall's The Wind Done Gone was a transformative use of Margaret Mitchell's novel Gone with the Wind). 
of copyright as either a hindrance or an anachronism. ${ }^{32}$ These new social movements have no determinate center, but include, to varying degrees, software developers and programmers, Internet pioneers, librarians, education institutions, the hacker community, new media enthusiasts, artists, various academics, and businesses that consume rather than produce intellectual property, or whose business models do not depend heavily on exploitation of intellectual property rights. The proponents and opponents of increased intellectual property protection began to fight battles on several different fronts, egged on by controversies surrounding digital music, encryption policy, and the application of the DMCA.

\section{B. Collection of Racial Data}

In the copyright example we have just examined, technological change alone did not alter the meaning of the free speech principle; rather, it provided an incentive and an opportunity for interested parties to offer new, competing interpretations of the jurisdiction of the free speech principle. Indeed, it was only as those interested in strengthening copyright protection succeeded in entrenching their understandings in law that growing numbers of citizens began to mobilize around the idea that the free speech principle limited the application of copyright to the new media. Both technological and legal change helped reshape the ecology of the free speech principle and spurred social movement contestation.

Our next example, involving the application of the antidiscrimination principle to government data collection, focuses specifically on how fundamental shifts in law can interact with other social and demographic trends to disturb the ecology of a principle's application, and supply the occasion and the motive for political actors to reinterpret the principle's meaning.

Today, most Americans believe it is wrong to discriminate on the basis of race. Yet few believe that asking census questions to collect demographic information about race falls within that prohibition. During the 1950s and 1960s, however, the civil rights movement was quite wary of government collection of racial data, viewing it as a practice likely to entrench segregation. After Brown, the Supreme Court decided several cases suggesting that government collection of racial

\footnotetext{
${ }^{32}$ See generally Barlow, supra note 27, at 89 (explaining some of the fundamental problems with copyright in the digital age and asserting that "information wants to be free").
} 
data-for example, on ballots ${ }^{33}$ — either manifested or stimulated racial prejudice, and therefore violated the antidiscrimination principle. $^{34}$ In this era, racial data collection remained a suspect practice, and some early fair employment laws prohibited employers from keeping racial records on their employees.

Views about the constitutionality of racial data collection began to shift with the enactment of the 1964 Civil Rights Act, which incorporated racial data collection into the enforcement apparatus of the nation's new antidiscrimination legislation. With passage of the 1964 Act, racial record-keeping was not only permitted, it was now required by federal antidiscrimination law. ${ }^{36}$ Passage of the Act prompted reassessment of the purposes for which government or employers might be collecting racial data, and so altered assumptions about the compatibility of racial data collection practices with the antidiscrimination principle.

During the 1960s, as government began to change the form and function of racial data collection, the attitude of the civil rights movement toward the practice shifted markedly. At a 1962 meeting of the American Statistical Association, for example, a spokesperson for the NAACP asserted that the organization "oppose[d] the compilation

33 See Anderson v. Martin, 375 U.S. 399, 402 (1963) (barring compulsory designation of race on a ballot on the grounds that it constituted "the placing of the power of the State behind a racial classification that induces racial prejudice at the polls").

${ }^{34}$ For example, in Tancil $v$. Woolls, 379 U.S. 19 (1964), the Supreme Court affirmed per curiam the lower court decision from Hamm v. Virginia State Board of Elections, 230 F. Supp. 156, 158 (E.D. Va. 1964), invalidating laws that separated voting and property records based on race, but upholding a law requiring that divorce decrees designate the race of the divorcees. The decision prohibited government from organizing public records by race where the state had no licit purpose for collecting racial information, but allowed the state to collect racial data about divorcing couples because it served the legitimate state purpose of maintaining vital statistics. The lower court reasoned that "the designation of race ... may in certain records serve a useful purpose, and the procurement and compilation of such information by State authorities cannot be outlawed per se. ... If the purpose is legitimate, the reason justifiable, then no infringement results." Hamm, 230 F. Supp. at 158; see also Whitus v. Georgia, 385 U.S. 545, 551 (1967) (finding an impermissible opportunity for discrimination in the state's selection of jurors from a racially segregated tax digest).

${ }^{35}$ See Owen M. Fiss, A Theory of Fair Employment Laws, 38 U. CHI. L. REV. 235, 265 (1971) ("At one point in the history of fair employment laws the requirement of color blindness was taken in its most expansive sense... The antidiscrimination prohibition was thought to preclude any form of record-keeping that identified the race of employees or applicants for employment. This ban is probably at an end.").

${ }^{36}$ See, e.g., Civil Rights Act of 1964, Pub. L. No. 88-352, tit. IV, § 402, 78 Stat. 247, 247 (codified as amended at 42 U.S.C. $\$ 2000$ c-1 (2000)) (requiring a survey to determine educational opportunity by race); see also Fiss, supra note 35, at $265 \&$ n.32 (citing regulations mandating the submission of racial census reports to public agencies). 
and publication of racially classified data on crime and illegitimate births because such information sheds no significant light on the causes, ... is subject to distortion and misrepresentation, and ... is utilized to thwart the drive toward an egalitarian, pluralistic society." ${ }^{37}$ The speaker, Henry Lee Moon, clarified, however, that the NAACP supported government collection of "[a] host of facts revealing the relative socio-economic status of the Negro." ${ }^{38}$ As racial designation and data collection became an integral part of the enforcement of civil rights legislation, the movement's stance toward the practice changed, and it ceased litigation in this area. ${ }^{39}$

With these changes in the form and function of the practice, the question of whether racial data collection was compatible with the antidiscrimination principle seemed to disappear from view. In the 1970s a few plaintiffs challenged the constitutionality of government collection of racial data for civil rights enforcement, but appellate courts brusquely rejected such claims, refusing to treat racial data collection as suspect in purpose or as an act of racial classification subject to strict scrutiny. ${ }^{40}$

${ }^{37}$ Henry Lee Moon, Statement to the American Statistical Association (1962), quoted in Albert Mindlin, The Designation of Race or Color on Forms, 26 PUB. ADMIN. REV. 110,115 (1966).

${ }^{38} I d$. at $115-16$.

39 See Hearings Before the Fed. Deposit Ins. Corp. 7-8 (Dec. 19, 1972) (statement of William L. Taylor, Director, Center for National Policy Review) (stating that despite previous opposition to racial data collection, civil rights groups "are now almost unanimous in the conclusion that racial record-keeping is an essential element of an effective civil rights enforcement program"), cited in Daniel A. Searing, Discrimination in Home Finance, 48 NOTRE DAME LAW. 1113, 1140 \& n.156 (1973); see also William L. Taylor, Federal Civil Rights Laws: Can They Be Made To Work?, 39 GEO. WASH. L. REV. 971, 997-98 (1971) (noting that civil rights advocates had opposed data collection in some contexts and urging that "[a]n effort by civil rights groups to resolve their differences and encourage the collection and use of such racial data with appropriate safeguards to protect the individual would be an important first step in persuading federal agencies to establish more realistic and workable systems of enforcement").

${ }^{40}$ In the 1970 s, federal courts twice held against constitutional challenges to government collection of racial data for the purpose of enforcing civil rights legislation. In United States v. New Hampshire, 539 F.2d 277, 277 (1st Cir. 1976), the First Circuit upheld the racial data requirements of Section 709 (c) of Title VII of the Civil Rights Act of 1964, Pub. L. No. 88-352, 78 Stat. 247, 263 (codified at 42 U.S.C. § 2000e-8(c) (1970)), as reasonable and within Congress's Fourteenth Amendment powers, without ever discussing whether the required collection of racial data was a racial classification. Two years later, when plaintiffs raised equal protection challenges to racial data collection pursuant to an Office of Civil Rights investigation of teacher placement in New York schools, the Second Circuit merely cited the First Circuit's decision to support its statement that "the Constitution itself does not condemn the collection of this data." See Caulfield v. Bd. of Educ., 583 F.2d 605, 611-12 (2d Cir. 1978). 
But after several decades in which racial data collection proceeded undisturbed in the midst of furious debate about the application of the antidiscrimination principle, constitutional questions about the practice are again arising. Debate about how the federal government would survey race in the 2000 Census focused attention anew on government collection of racial data, drawing into question the presumption that the practice was benign. This debate produced at least one lawsuit advancing a Fifth Amendment challenge to the racial identification questions on the 2000 Census. ${ }^{41}$ But the judge was not receptive to the claim, refusing to analyze the questions about race on the census as racial classifications subject to strict scrutiny, with the terse observation that "[p]laintiffs' position is based upon a misunderstanding of the distinction between collecting demographic data so that the government may have the information it believes at a given time it needs in order to govern, and governmental use of suspect classifications without a compelling interest." ${ }^{42}$ Although the census supplied the categories through which racial identity could be expressed, those surveyed were responsible for determining their own race. Because the census questions required individuals to engage in racial self-classification, the judge emphasized, they were not subject to heightened judicial scrutiny, so long as the information gathered was not used for discriminatory purposes. ${ }^{43}$ As this example illustrates, courts remain unwilling to analyze racial data collection which they believe serves racially egalitarian aims as a racial classification subject to the presumption of unconstitutionality.

But the challenge to the 2000 Census was an early sign of several new waves of social movement activity dedicated to persuading Americans that racial data collection is a practice of racial classification that can threaten civil rights values. Groups with different political orientations targeted the census, some seeking a more fluid categorization of race (e.g., "multiracial" categories), ${ }^{44}$ and others, like those who filed suit, seeking to prohibit government inquiry into race altogether.

${ }^{41}$ See Morales v. Daley, 116 F. Supp. 2d 801, 820 (S.D. Tex. 2000) (holding that census questions asking for racial self-classification do not violate equal protection or First Amendment rights).

${ }^{42}$ Id. at 814 .

${ }^{43}$ See id. at $814-15$ ("The issue raised by the plaintiffs is one properly addressed by Congress, not by the courts.").

${ }^{44}$ For an analysis of data collection as a practice of racial construction, and an account of social movement advocacy concerning the 2000 Census, see Naomi Mezey, Erasure and Recognition: The Census, Race and the National Imagination, 97 Nw. U. L. REV. 1701, 1749-64 (2003). 
Recent challenges to the census have more bite than their precursors for two reasons. First, as the demand for a multiracial category illustrates, advocates across the political spectrum now agree that census categories do not merely describe race; they also construct race. ${ }^{45}$ Second, the claim that racial data collection violates the antidiscrimination principle is more credible than it was in the 1970s because, in the intervening decades, critics of civil rights laws have persuaded courts that the antidiscrimination principle restricts race-conscious civil rights regulation, such as affirmative action. ${ }^{46}$

The link between these new civil-rights-restrictive interpretations of the antidiscrimination principle is most visible in California constitutional politics. Ward Connerly, who several years ago led a ballot initiative to prohibit government-sponsored affirmative action in the state, ${ }^{47}$ recently championed another state constitutional proposal (Proposition 54) known as the Racial Privacy Initiative (RPI), which would bar government collection of racial data for civil rights enforcement. Advocates for the RPI argued that racial data collection violates the antidiscrimination principle-a claim they buttressed by invoking Thurgood Marshall's arguments in Brown v. Board of Education, the legacy of Martin Luther King, Jr., and the memory of slavery

${ }^{45}$ See id. at 1702 ("The racial categories of the census have made and unmade racial identity as the boundaries of those categories have shifted over time ....").

${ }^{46}$ See, e.g., Adarand Constructors, Inc. v. Pena, 515 U.S. 200, 227 (1995) (holding that all government actions based on race, including affirmative action programs, are subject to strict scrutiny); City of Richmond v. J.A. Croson Co., 488 U.S. 469, 505-11 (1989) (striking down a race-conscious government contracting program under strict scrutiny). See generally Siegel, Equality Talk, supra note 5, at 1513-32 (describing early claims that the antidiscrimination principle restricts civil rights initiatives, and the blossoming of the affirmative action debates in the 1970s).

${ }^{47}$ Connerly's proposal, known as Proposition 209, was adopted by California voters in 1996 as Article 1, Section 32 of the California Constitution, and, a year later, the Ninth Circuit upheld it against attack on equal protection and preemption grounds. Coal. for Econ. Equity v. Wilson, 122 F.3d 692, 710 (9th Cir. 1997). 
and segregation. ${ }^{48}$ After national debate, Proposition 54 was defeated in $2003,{ }^{49}$ but the question it posed seems likely soon to reappear. The claim that collecting racial data for civil rights enforcement violates the antidiscrimination principle has recently gained plausibility from a new source, as the civil rights movement itself has begun to suggest that the antidiscrimination principle imposes limits on racial data collection for criminal law enforcement (e.g., "driving while black" and "flying while brown"). ${ }^{50}$ Although challenges to the census and to racial profiling come from very different political quarters, each challenge supports the other as it claims that government collection and use of racial data is a practice to which the anticlassification principle might apply.

\footnotetext{
${ }^{48}$ Press releases and campaign materials from the "Yes on Proposition 54" campaign summon the Brown legacy explicitly and more subtly, drawing on the values of anticlassification and colorblindness. See Ward Connerly, Statement to UC Board of Regents (May 15, 2003), http:/ /web.archive.org/web/20041127180033/www.racialprivacy.org/ content/miscellaneous/regents_board.php ("In 1954, Thurgood Marshall described racial classifications as 'odious' when he represented the NAACP in Brown v. Board of Education. At that time, the NAACP opposed racial classifications and racial categories and the so-called 'one-drop' rule." (italics added)). In other aspects of campaign advocacy, the reference to Brown is somewhat less explicit. See, e.g., Press Release, Racial Privacy Initiative, Prop 54 Campaign Chair Ward Connerly Slams Ninth Circuit Court's Gross Mischaracterization of Prop 54 as "A Ridiculous Lie" (Sept. 15, 2003), http:// web.archive.org/web/20041105094054/www.racialprivacy.org/content/press/sept15_ 2003.php ("[The RPI is] about whether or not the government has a right to recognize its citizens by race and classify them accordingly. ... [This] has led to practices like Jim Crow and the internment of American citizens."). RPI supporters have followed the campaign's lead in linking the symbol of Brown to Proposition 54. See, e.g., George F. Will, Dropping the "One Drop" Rule, NeWsweEk, Mar. 25, 2002, at 64 ("Who can object to the RPI 48 years after Thurgood Marshall, then ... representing the NAACP in Brown v. Board of Education, said, 'Distinctions by race are so evil, so arbitrary and invidious that a state bound to defend the equal protection of the laws must not involve them in any public sphere'?").

${ }^{49}$ See Official Declaration of the Result of the Statewide Special Election (Oct. 7, 2003), http://www.ss.ca.gov/elections/sov/2003_special/sum.pdf (declaring that Proposition 54 was defeated $64 \%$ to $36 \%$ ).

${ }^{50}$ Debate has focused on the ways that government uses race to construct law enforcement "profiles" of criminals to guide in the apprehension of suspects. These concerns extend to the generation and use of suspect descriptions for law enforcement. For cogent expression of the complex arguments in this debate, see Brown $v$. City of Oneonta, 235 F.3d 769, 779-89 (2d Cir. 2000) (Calabresi, J., dissenting from denial of rehearing en banc) (exploring institutional considerations that shape analysis of whether the use of race in a suspect description is a "classification" subject to strict equal protection scrutiny); R. Richard Banks, Race-Based Suspect Selection and Colorblind Equal Protection Doctrine and Discourse, 48 UCLA L. REV. 1075, 1090-1107 (2001) (questioning the common assumption that there is a constitutionally significant distinction between using race in suspect descriptions and in criminal profiles).
} 
As the census and copyright examples have illustrated, the jurisdiction of a constitutional principle may be fixed and sustained by habit over such long periods of time that the boundaries of the principle's application are no longer visible or examined. Such a resolution can hold for decades, until advocates prompt renewed attention to, and interrogation of, the principle's jurisdiction. Often such challenges are motivated and enabled by changes in law or technology that affect the ecology of a principle's proper application. Contending social groups avail themselves of the opportunity such changes present to propose new claims about the meaning and practical implications of constitutional principles.

Presently courts are able to reconcile copyright with the free speech principle, and the census with the antidiscrimination principle; yet, because of social movement contestation, they must do intellectual work to reconcile principle and practice where none was required before. The reasoning that reconciles principle and practice is vulnerable to critique and questioning-in significant part because the social arrangements that the reconciliation of principle and practice serve are now subject to ongoing challenge.

\section{The Presuppositions of PRINCIPLED ARGUMENT: LEGITIMACY AND FEASIBILITY}

When a practice is challenged as contrary to an important constitutional principle, one way to defend it is to offer mediating distinctions that distinguish the challenged practice from other practices to which the principle is commonly applied. This process preserves the practice by showing how it does not fall under the principle; equally important, it preserves the principle by limiting its scope and jurisdiction. For example, the legitimacy of collecting racial data in the census may be defended on the ground that the government is not making racial distinctions, but simply collecting self-reported racial distinctions. Suspect descriptions can be defended on the ground that the government is not making racial classifications but is merely acting on information provided by third parties, or on the ground that the government's investigative criteria are not racial classifications because race is only one of several factors. The legitimacy of copyright can be defended by arguing that the government is aiming at conduct (copying) and not at the suppression of particular content or viewpoints. Campaign finance regulation can be justified on the grounds that the government is attempting to regulate conduct (corruption or the appearance of corruption) and not expression, and 
that contributions are different from expenditures. The legitimacy of broadcast regulation can be defended by arguing that the government is offering a quid pro quo for free use of a scarce resource (broadcast spectrum).

Once a principle calls a practice into question, those who would defend the challenged practice must develop a rationale for distinguishing the practice from other practices to which the principle applies. The distinction between race as a sole factor and race as one of multiple factors limits the reach of the antidiscrimination principle, just as the scarcity rationale can be deployed to limit the free speech principle. Further political contestation, however, can disrupt these mediating strategies. At some point a rationale no longer appears plausible or legitimate, and that is the point at which it begins to break down as a method of legitimation. This is what happened with the scarcity rationale during the 1980s, when the FCC embarked on a period of whole-scale deregulation of the broadcast media and abolished the fairness doctrine that the Court had upheld in Red Lion $v$. FCC. ${ }^{51}$

In fact, the mediating distinction that limits the reach of a principle actually is doing other work: it is a proxy for a series of judgments, including (as we have seen) the legitimacy of the practice, the felt social importance of the practice, and the institutional competence of courts or legislatures to regulate the practice. Political contestation of a practice brings these features into sharper focus. In Brown v. City of Oneonta, for example, the Second Circuit rejected an equal protection challenge to racial suspect descriptions, concluding that the suspect descriptions were not racial classifications on the basis of formal criteria, such as the fact that race was not the sole factor employed in the search. ${ }^{52}$ Yet several judges concurring in and dissenting from the Second Circuit's denial of rehearing en banc made clear that the question of whether a race-based suspect description is a racial classification implicates a variety of constitutional values and pragmatic institutional considerations. Judges were concerned that application of the anticlassification principle would hamstring police investigations and that courts would not be very good at supervising what police offi-

${ }^{51}$ See In re Syracuse Peace Council, 2 F.C.C.R. 5043, 5057 (1987) (“[T]he fairness doctrine contravenes the First Amendment and thereby disserves the public interest.").

${ }^{52} 221$ F.3d 329, 337-38 (2d Cir. 2000) ("In acting on the description provided by the victim of assault-a description that included race as one of several elementsdefendants did not engage in a suspect racial classification that would draw strict scrutiny."). 
cers did in developing and using suspect descriptions. ${ }^{53}$ But they were also concerned about the prevalence of racial bias in criminal law enforcement. ${ }^{54}$ In other words, judges looked to the role of courts in safeguarding certain constitutional values, the threat to constitutional values certain practices posed, the social importance of the challenged practice, and the institutional competence of courts to oversee reforms in the challenged practice. These opinions deploy the sole criterion/multiple criterion test as a proxy for circumstances in which courts think that police practices are especially problematic and so may require judicial oversight, whatever its countervailing costs. ${ }^{55}$

Similar considerations apply to First Amendment challenges to extensions of copyright. To preserve copyright law from First Amendment difficulties, courts may offer the speech/conduct distinction or the principle that regulations of copyright are reasonable time, place, and manner regulations rather than content- or viewpoint-based restrictions. But behind these doctrinal moves are a set of more basic concerns and interpretive judgments, about whether copyright extension poses a sufficiently real and important threat to free expression; whether piracy is a serious problem that needs to be kept under control; whether media companies are systematically abusing their use of intellectual property, or whether the complained of practices are rela-

${ }^{53}$ See, e.g., Brown v. City of Oneonta, 235 F.3d 769, 777 (2d Cir. 2000) (Walker, C.J., concurring in denial of rehearing en banc) (describing the "unworkability" of a regime in which "[o]fficers would be forced to justify the[ir] intuitive considerations in order to meet an accusation that race was the sole factor motivating the encounter").

${ }^{54}$ See id. at 783 (Calabresi, J., dissenting from denial of rehearing en banc) ("[T]he[] statements in the pleading ... support precisely the claim that the police went beyond the victim's description and created their own racial classification."); see also id. at 789 n.16 (Straub, J., dissenting from denial of rehearing en banc) ("No less than when they rely upon racial classifications of their own making, the police impose tremendous social costs upon people of color when they act primarily upon the racebased suspicion of victims and other witnesses.").

${ }^{55}$ In other words, judgments about whether practices are racial classifications for purposes of equal protection law have a significant policy-based component. Since the Second Circuit denied rehearing en banc, the plaintiffs in the Oneonta case have turned to the New York state courts to determine whether the use of race as an element in a suspect description is a racial classification under the equal protection clause of the state's constitution. See Brown v. State, 776 N.Y.S.2d 643, 646-47 (App. Div. 2004) (" $[\mathrm{A}] \mathrm{n}$ adverse federal court decision on an equal protection claim under the U.S. Constitution does not preclude litigation for the first time of a state equal protection claim in state courts."). And in other practical contexts, federal courts have found that government policies employing race as one of multiple criteria are racial classifications for purposes of federal equal protection law. See Balkin \& Siegel, The American Civil Rights Tradition, supra note 7, at 16-17 (observing that federal courts employ different standards for determining whether a practice classifies on the basis of race when analyzing policies concerning suspect apprehension and affirmative action). 
tively isolated; whether Congress has been captured by special interests that are hampering legitimate free speech practices; and how easy it will be for courts to draw lines regarding the proper length of the copyright term.

\section{SOCIAL MOVEMENTS AS DISRUPTORS}

Shifts in attitudes about the scope and extension of principles do not occur in a vacuum. Principles do not become unstuck by themselves. These changes require institutions that disrupt public understandings, contest received framings, and help reshape and reform public opinion. Social movements play a key role in this process. Drawing on traditions of argument in American constitutional culture, movements extend existing principles to new practices and dislodge existing principles from their accustomed regulatory surroundings. ${ }^{56}$ To borrow a phrase from T.S. Eliot, social movements are important because they dare to disturb the universe. ${ }^{57}$

The law needs social movements, even as social movements disrupt legal orderings. Social movements continuously integrate law and the institutions of civil society. They connect legal norms to the beliefs and practices of ordinary people, so as to preserve a relationship between what the law regards as licit and what the public does. This connection to the social order secures the normative vitality of the law, making it legitimate, efficacious, and practically enforceable.

Because political mobilization disrupts the social order, it also disturbs the law's connection to that order, and, in time, brings about legal change, whether that change is manifested in the work of legislatures, courts, or both. Thus, social movements give nongovernmental actors an opportunity to talk back to institutions of power and to have a voice in the development of constitutional norms. Social movement contestation provides informal channels through which people can

${ }^{56}$ See Jack M. Balkin, How Social Movements Change (or Fail To Change) the Constitution: The Case of the New Departure, 39 Suffolk L. REV. 27, 52 (2005) (noting how social movements help shape the contours of constitutional reasoning, moving claims from being "off-the-wall" to being central examples of constitutional common sense); Siegel, Constitutional Culture, supra note 5 (showing how American constitutional culture encourages citizens to make partisan claims by appeal to public values with the result that citizens continually justify new claims of constitutional meaning by invoking the authority of older constitutional understandings that the community recognizes and shares).

${ }^{57}$ See T.S. ELIOT, The Love Song of J. Alfred Prufrock (1917), reprinted in THE COMPLETE POEMS AND Plays 1909-1950, at 4-5 (Harcourt Brace Jovanovich 1980) ("Do I dare / Disturb the universe?"). 
engage formal legal institutions about the direction and pace of constitutional development. ${ }^{58}$

Courts play an important and creative role in this process, but it is largely a reactive role. Courts respond to social disruption by social movements rather than initiate it themselves; they reconstitute and reformulate law in the light of political contestation, rationally reconstructing and synthesizing changes in political norms with what has come before. Courts arrive in medias res, absorbing the shocks caused by social movements and assisting in the reconstitution of social understandings in the wake of movement struggle. ${ }^{59}$

To be sure, the work of courts helps shape public opinion, but courts are not public opinion's only resource. Social movementswhich include both mobilizations and countermobilizations-play a key role in disrupting norms and expectations about legitimacy and illegitimacy. Litigation before courts is only one of many possible fora in which movements fight these battles. ${ }^{60}$ Judicial opinions may codify gains or losses in such struggles, but courts rarely have either the first or last word. For example, the Supreme Court's 2003 decision in Eldred $v$. Ashcroft $t^{61}$ did not resolve the status of copyright law under the First Amendment. Rather, it was merely one moment in what promises to be a long battle over the meaning of the free speech principle in the digital era. Because the case arrived at the Supreme Court early in the development of the social movement for "free culture," it is hardly surprising that the Supreme Court was not particularly sympathetic to the claims of the movement. ${ }^{62}$ Indeed, what is surprising is

58 See Reva B. Siegel, Text in Contest: Gender and the Constitution from a Social Movement Perspective, 150 U. PA. L. REv. 297, 351 (2001) [hereinafter Siegel, Text in Contest] (" $[\mathrm{W}]$ hen the Constitution has multiple and socially dispersed interpreters, the Court is likely to interpret the Constitution in ways that are informed by evolving popular judgments about the Constitution and issue judgments that find support among a diverse array of social actors.").

${ }^{59}$ See Jack M. Balkin, What Brown Teaches Us About Constitutional Theory, 90 VA. L. REV. 1537, 1546, 1549-50 (2004) [hereinafter Balkin, What Brown Teaches Us] (arguing that when it comes to promoting social change, courts "are bad at tackling, good at piling on" and that courts generally "confirm what has already been happening in the larger legal and political culture").

${ }^{60}$ Indeed, the debate occasioned by a notable public case may be as important to the development of public norms in the long run as the decision in the case itself.

${ }^{61} 537$ U.S. 186, 197-98 (2003) (holding that the Copyright Term Extension Act did not violate either the Copyright Clause or First Amendment).

${ }^{62}$ For an exposition of some of the principles of the free culture movement, and their articulation in the Eldred litigation, see generally LAWRENCE LESSIG, FREE CULTure: How Big Media Uses Technology and the Law To Lock Down Culture AND CONTROL CREATIVITY 228-47 (2004). 
that the Court took the case in the first place. Eldred forestalls, for the time being, the development of a robust First Amendment jurisprudence in this area, giving defenders of strong intellectual property rights a firm legal foothold. But Eldred will hardly be the last word, and the real battle will be waged elsewhere, as the struggle to change public opinion about how intellectual property affects creativity and free expression is fought out in a thousand different locations.

We might make a rough (if imperfect) analogy between the defeat of the incipient social movement for free culture in Eldred and the defeat of the gay rights movement in Bowers $v$. Hardwick, ${ }^{63}$ a defeat which was eventually overturned in Lawrence $v$. Texas. ${ }^{64}$ Although the gay rights movement was almost twenty years old when the Court decided Bowers, the movement had not captured the public's imagination to the degree it has today, and the country was in the grips of fear about AIDS. Seventeen years later, when the Supreme Court decided Lawrence, the movement had changed public attitudes sufficiently to call into question the use of the criminal law to punish homosexuals for their sexual orientation. Judged in hindsight, it is clear that the Supreme Court's decision in Bowers did not conclusively decide the meaning of liberty. It was merely a way station in a larger struggle over constitutional norms. Indeed, the judicial pronouncement in Bowers, far from arresting the debate over constitutional norms, served only to propel the discussion forward. Lawrence, too, is hardly the conclusion of the story, as we can see in the ongoing struggle over same-sex marriage.

Social movements, in short, play a crucial creative role in legal ordering. They construct the semantic normative climate in which people talk about the great constitutional issues of the day. Social movements apprehend and construe social, economic, and technological change. They reinterpret the changing scene of regulation. They give people a sense of who they are and why they should be aggrieved by existing practices. They help construct interests, aims, and norms. Finally, they can play an important role in reorienting law to shifting social understandings so that legal and social institutions remain in dynamic relation to one another. This is what is happening today in the struggle over the scope of intellectual property rights and the First Amendment. A loose collection of computer developers, artists, con-

${ }^{63} 478$ U.S. 186, 195-96 (1986) (holding that a Georgia statute criminalizing sodomy did not violate the Due Process Clause).

${ }^{64} 539$ U.S. 558, 578-79 (2003) (overturning Bowers and holding that a Texas statute outlawing homosexual sex violated liberty protected by the Due Process Clause). 
sumer advocates, academics, and end users are coming to understand themselves as aggrieved by the expansion of intellectual property rights and the legitimation of this expansion by courts and legislatures. They are beginning to form a social movement, seeing themselves as people who have interests in common and, equally important, share common values in a struggle for legal reform. And they are invoking longstanding legal principles in ways that force the legal system to reckon with their concerns.

Social movements do not possess formal authority in the legal system (although some members of social movements may be lawmakers or other political officeholders). Nevertheless, they can change the meaning of constitutional norms, and thus alter the constitutional legitimacy or illegitimacy of particular social practices. That is because movements disrupt and help reformulate the social order on which the law and the courts ultimately depend. Even without the formal authority to make law, social movements have the power to change the meaning of law and to alter the normative climate in which laws are interpreted and understood. They can undermine or support the legitimacy of existing practices, dislodge long agreed-upon principles, and nourish new constitutional norms. They can make principles apply to practices to which the principles never before seemed applicable. They can assert the legitimacy of practices previously thought illegitimate. Because of social movement contestation, law can mean things that it did not mean before. ${ }^{65}$

But if social movements have the power to unsettle legal orderings and disrupt understandings about what is legitimate and illegitimate, they are rarely able to achieve all that they seek. Although social movements disturb settled meanings, they do not fully control how social meanings will shift and resettle as a result of their disruptions. Successful social movements almost always produce countermobilizations that arise to contest them. The push and pull of mobilization and countermobilization produces a new balance of understandings about which practices are socially licit and illicit, and about which exercises of public power are constitutionally legitimate and illegitimate.

\footnotetext{
${ }^{65}$ See Siegel, Text in Contest, supra note 58, at 317-18 (analyzing features of constitutional culture that enable mobilized citizens to shape constitutional understandings, even where they lack official authority to interpret the Constitution, and noting that "it is through pathways of meaning that all manner of social actors can shape law, even when no formal act of lawmaking transpires" (footnote omitted)).
} 
And the struggle to persuade the polity to embrace a movement's aims often transforms the movement's advocates. ${ }^{66}$

The current struggle over same-sex marriage is a good example of these processes at work. As the gay rights movement has made new claims about the jurisdiction of the antidiscrimination principle, it has begun to call into question a variety of laws and practices that discriminate against homosexuals. Not only has it challenged the use of the criminal law to punish homosexuals, it has asserted claim to the equal benefits of civil law, seeking respect and recognition for samesex relationships in marriage. Yet the movement's very success in questioning norms that forbid the marriage of same-sex couples has spurred countermovements determined to preserve traditional understandings of marriage. In this struggle, neither side wholly commands the public's confidence, and so each has power to shape the other's claims. Defenders of tradition have turned to the state to entrench practices in ways that custom no longer will, endeavoring to persuade an increasingly uncertain public that using law to exclude gays from marriage is not prejudice, bigotry, or hate. At the same time, decades of debate with critics who claim that gay rights threaten traditional family values may have pressured a movement for secular freedom to express claims for dignity, recognition, and respect as claims for access to that most traditional of institutions, marriage.

Social movements call into question longstanding legal arrangements. Often they achieve reform in response to their concerns. But rarely can movements completely realize their aims in law. More often, a movement's aims are transformed in the quest.

\footnotetext{
${ }^{66}$ See Balkin, What Brown Teaches Us, supra note 59, at 1558-63 (describing political limits on social movements, including the role of countermobilizations); Siegel, Constitutional Culture, supra note 5 (showing how a constitutional insurgency that begins to persuade the public of its claims will often elicit countermovements seeking to defend the constitutional understandings an insurgency has challenged, and demonstrating how movement and countermovement will engage and shape one another in this quest for the public's confidence).
} 